\title{
Innovative Technologies of the Provincial Museums as a Development Resource of an Internal Tourism
}

\author{
*1Elena Y. Nuikina, ${ }^{2}$ Natalia V. Polyanskova \\ ${ }^{* 1}$ Associate Professor of the Department of Higher Mathematics and Economic and Mathematical Methods, Samara \\ State University of Economics \\ ${ }^{2}$ Associate Professor of the Department of Regional Economics and Management, Samara State University of \\ Economics \\ E-mail: ${ }^{*}$ nuikina1973@mail.ru, ${ }^{2}$ polynskova@mail.ru
}

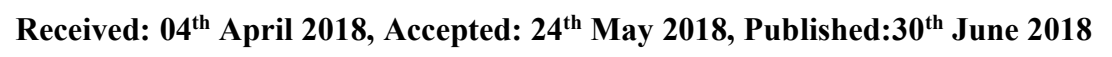

\begin{abstract}
Relevance of the studied problem is caused by a role of the provincial museums in preservation of the historical territory heritage, patriotic, esthetic, moral education of youth. The article aims to identify the most popular activities of visitors to museums, museology innovative technologies and their potential as a resource for the development of domestic tourism. The leading methods of a research became: sociological poll of the Samara studying youth aged from 14 up to 25 years, observation, the analysis of the tourist routes projects developed by the municipal museums for participation in a competition on the best route of the small cities and villages of the Samara region. Practical recommendations which can promote increase in interest of the studying youth in visit of the municipal museums are formulated, namely: active introduction an information and communication technologies in the museums work; intensive development of educational entertainment programs, the organization of exhibitions, master classes with use of modern interactive methods; develop programs to optimize the placement of museums in rural areas; improvement of financial investments structure in museum business at the expense of the raised funds. Article submissions will be useful to museum managers, municipalities, the organizers of tourist leisure and tourism industry leaders for more effective organization of museums to increase their attendance.
\end{abstract}

Keywords: Museum Services, Patriotic Education, Provincial museum, Samara Region, Tourist Routes.

\section{Introduction}

Internal tourism becomes the most important direction of the Russian economy. It is connected with need of innovative projects and service trades development, reducing a share of the extracting industries in national economy. Feature of an end tourist product - the emotions received by travelers during a trip making tourism one of the priority needs of modern man (Joseph, Pine, Gilmore, 1999) [1]. The Russian researchers note that tourism in the Russian regions is a source of development of small business (Chibir \& Shirko, 2015) [2].

It is obvious that the significant role in development of internal tourism in the Russian regions is played the local museums. The modern museum is the not only scientific and educational organization combining selection, restoration, storage and an exposition of historical and cultural values. Today the museum is the difficult multilevel system solving a number of socially important problems among which more and more noticeable positions are taken the art organization of leisure, integration of cognitive and moral and patriotic activity.

The museum promotes creation of new resources of the cultural environment. According to D. Throsby's theory (2001) [3], Professor of Economy at Macquarie University (Sydney, Australia) the cultural capital accumulated in material cultural values can have a considerable impact on the economic growth and the economic stability and investments. At the same time the material and non-material cultural assets may be regarded also both as a final consumption subject and an intermediate product in the process of production of other values influencing the large-scale economic processes and indices.

Quite a lot of research examines the potential development of different types of tourism: event, gastronomic (Jakosuo, 2011) [4], cinema (Dzhandzhugazova et al. 2016) [5], however, the role of museums in the development of domestic tourism has been little studied. Article of the Romanian researchers devoted to informative tourism is of interest to this work (heritage tourism) (Surugiu \& Surugiu, 2015) [6]. Authors emphasize special sensitivity of this type of tourism to the level of service and information escort of consumers. In modern conditions the municipal museums need to develop strategy of effective development. Its development can be promoted by detection of preferences of potential tourist services consumers and the analysis of the municipal museums readiness for innovative activities according to these preferences.

\section{Materials and Methods}

Thus, the main method of study was a sociological analysis conducted on the basis of survey method. A team of scientists of the Samara State University of Economics (SSEU) conducted a study to identify the level of interest of young students to visit museums in small towns and villages, to determine the degree of influence on the moral and patriotic education of youth museums municipalities. The museum audience of the Samara region became an object of a research (potential and real museum visitors aged from 14 up to 25 years). The sample - 1,100. Students of 3 large universities of the Samara region were interviewed - 
Samara State University of Economics, Samara State Technical University, Samara State Aerospace University named after Academician S.P. Korolev, pupils of 5 schools of Kinel-Cherkassky, Krasnoyarsk, Shigonsky, Bezenchuksky and Sergiyevsky districts. Data are collected through poll of pupils of educational institutions of the higher and secondary professional education of the Samara region - partially through online poll on social networks, partially in paper form by means of the work organization in student's groups and the organization of exit student's expeditions to municipal districts schools of the Samara region). The analysis of the museums public activity in the process of competition for the best project of the tourist route in the Samara region small cities and villages became the second method. The competition has been organized within the framework of the first phase of the atlas of tourist routes of the Samara region small cities and villages with the Russian Geographical Society financial support.

\section{Results}

To achieve this goal the following tasks were set in the framework of the study:

1. Based on the opinion poll:
- Level assessment of the municipal museums attendance by young people, as one of the defining factors of museum activity;

- determine the awareness degree of the younger generation about the provincial museums of Samara Region;

- Identification the reasons of rare visit the «small» museums;

- Establishment the most effective channels of informing public about museum activities;

- Definition of target orientations of museum audience;

- definition the priority activities of museum institutions in order to improve their performance, and also the formulation for this directions the practical recommendations aimed at improving the moral and patriotic education of youth.

2. Based on the analysis of the municipal museums participation in the regional competition «The best project of the small towns and villages tourist route of the Samara region»:

- Identification of the museum's innovative technologies that are used in the process of creating the project guided tours or tourist route.

The data of the sociological survey are presented in the following diagrams:

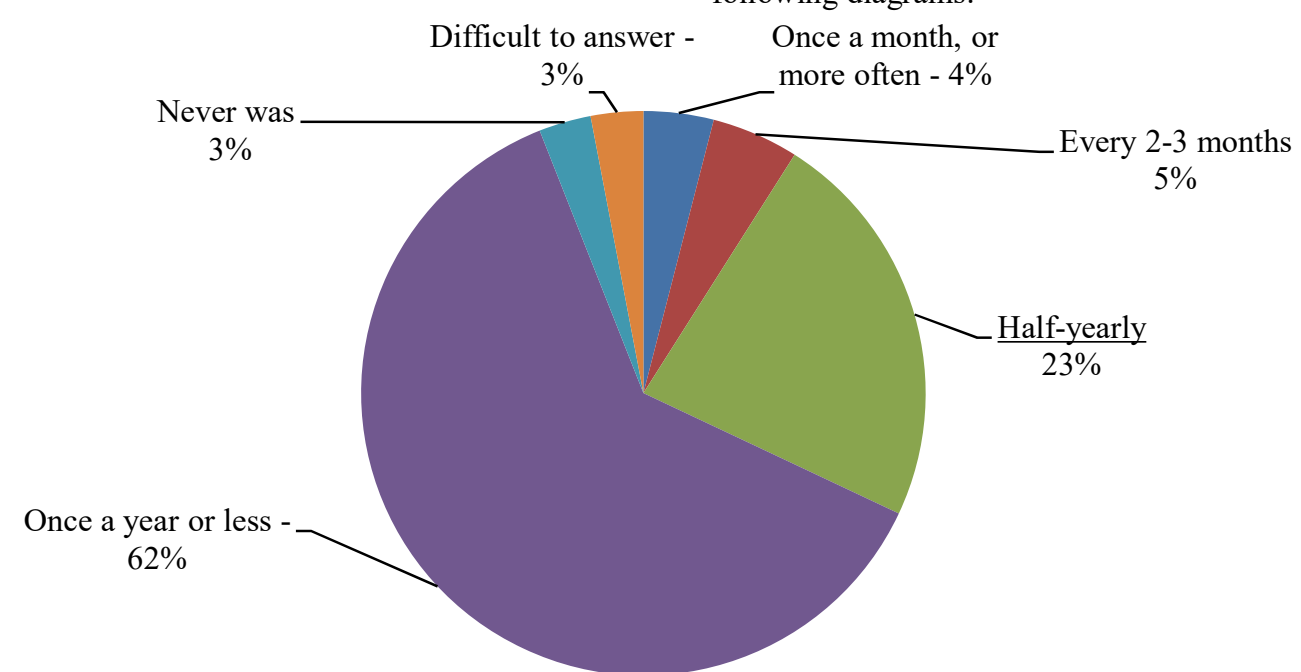

Fig. 1. The Level of Attendance of the Museums Young People (in \% of respondents)

Source: The results of the analysis of museum audience questioning of the Samara region.

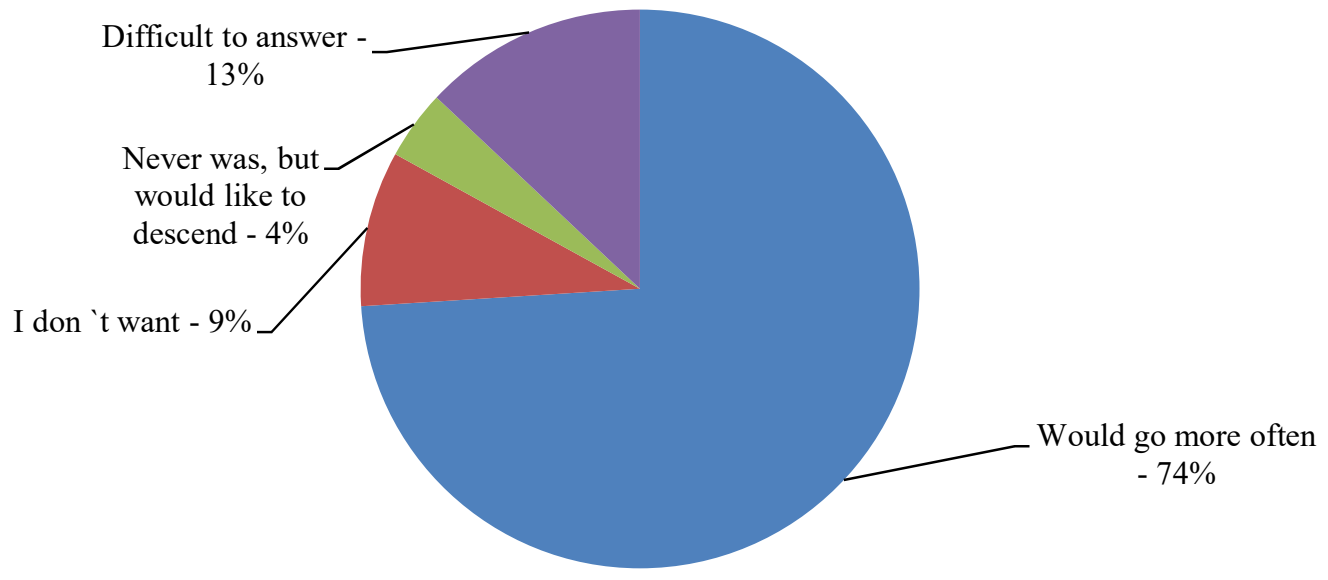


Fig. 2. The Desire of Young People to Visit Museums More Often (in \% of respondents)
Source: The results of the analysis of museum audience questioning of the Samara region.

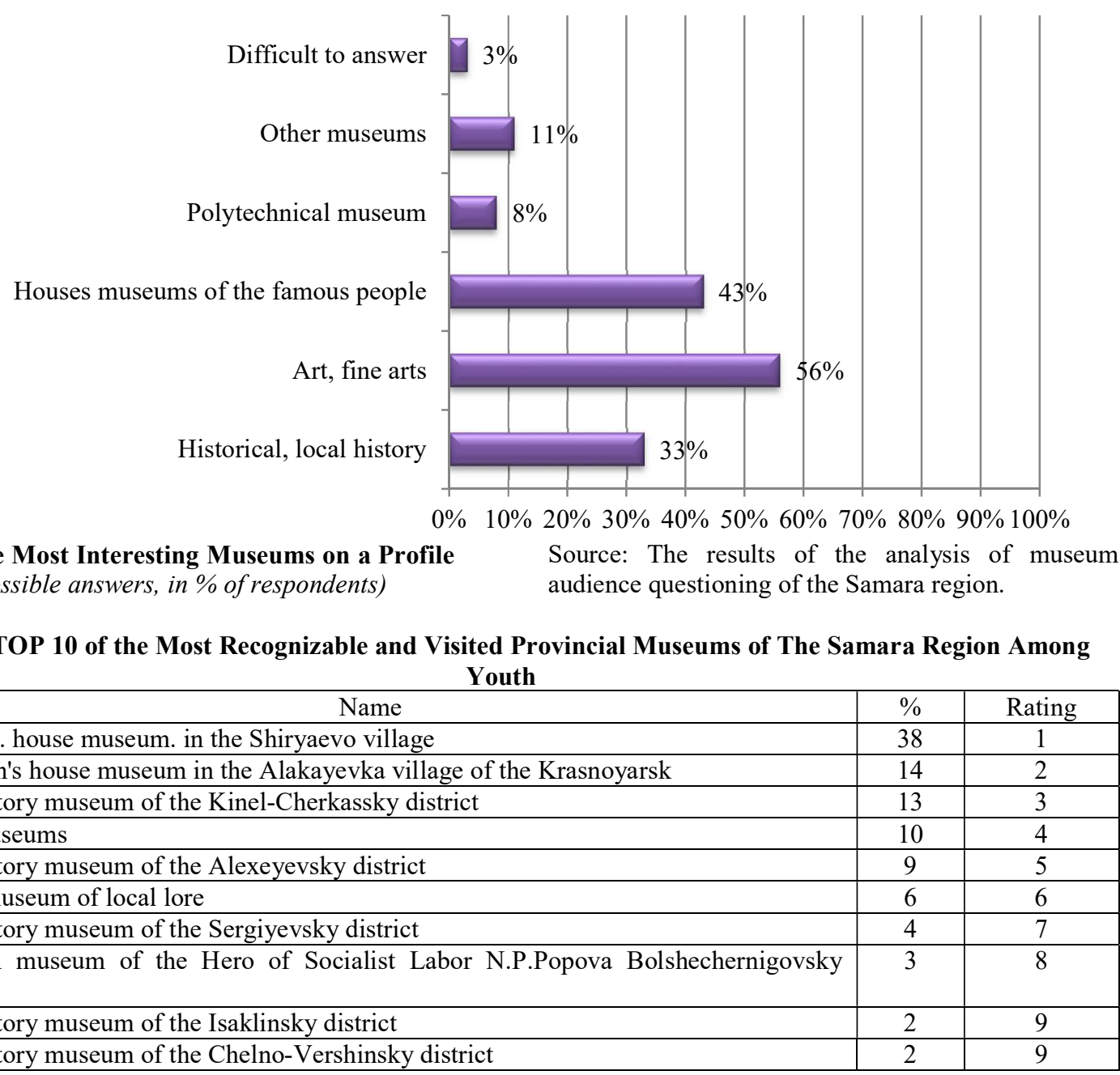

Fig. 3. The Most Interesting Museums on a Profile (several possible answers, in \% of respondents)

Source: The results of the analysis of museum audience questioning of the Samara region.

Tab.1. TOP 10 of the Most Recognizable and Visited Provincial Museums of The Samara Region Among

\begin{tabular}{|c|c|c|}
\hline Name & $\%$ & Rating \\
\hline Repin I.E. house museum. in the Shiryaevo village & 38 & 1 \\
\hline V.I. Lenin's house museum in the Alakayevka village of the Krasnoyarsk & 14 & 2 \\
\hline Local history museum of the Kinel-Cherkassky district & 13 & 3 \\
\hline Other Museums & 10 & 4 \\
\hline Local history museum of the Alexeyevsky district & 9 & 5 \\
\hline Borsky museum of local lore & 6 & 6 \\
\hline Local history museum of the Sergiyevsky district & 4 & 7 \\
\hline $\begin{array}{l}\text { Historical museum of the Hero of Socialist Labor N.P.Popova Bolshechernigovsky } \\
\text { District }\end{array}$ & 3 & 8 \\
\hline Local history museum of the Isaklinsky district & 2 & 9 \\
\hline Local history museum of the Chelno-Vershinsky district & 2 & 9 \\
\hline
\end{tabular}

Source: The Results of the Analysis of Museum Audience Questioning of The Samara Region.

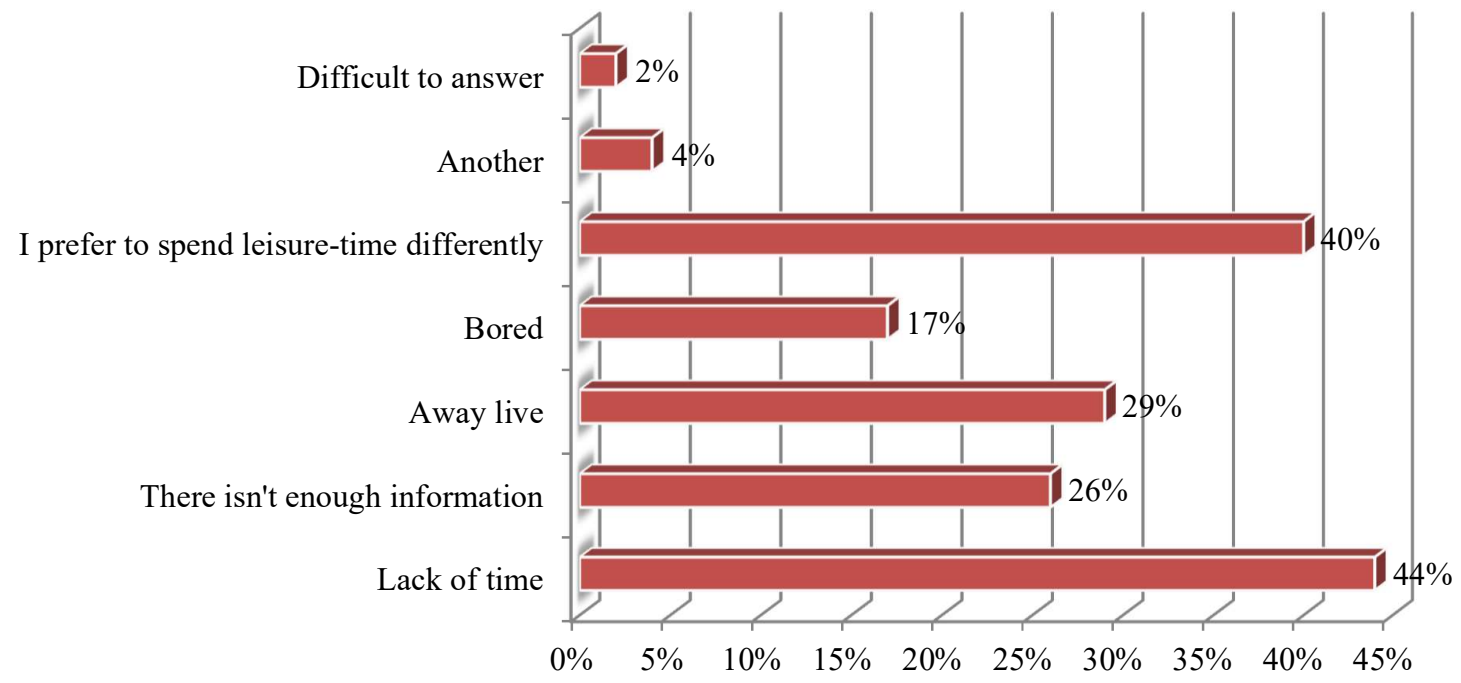

Fig. 4. The Reasons for a Rare Visit to The Small Museum (several possible answers, in \% of respondents) Source: The results of the analysis of museum audience questioning of the Samara region. 
Helix Vol. 8(4): 3454- 3464

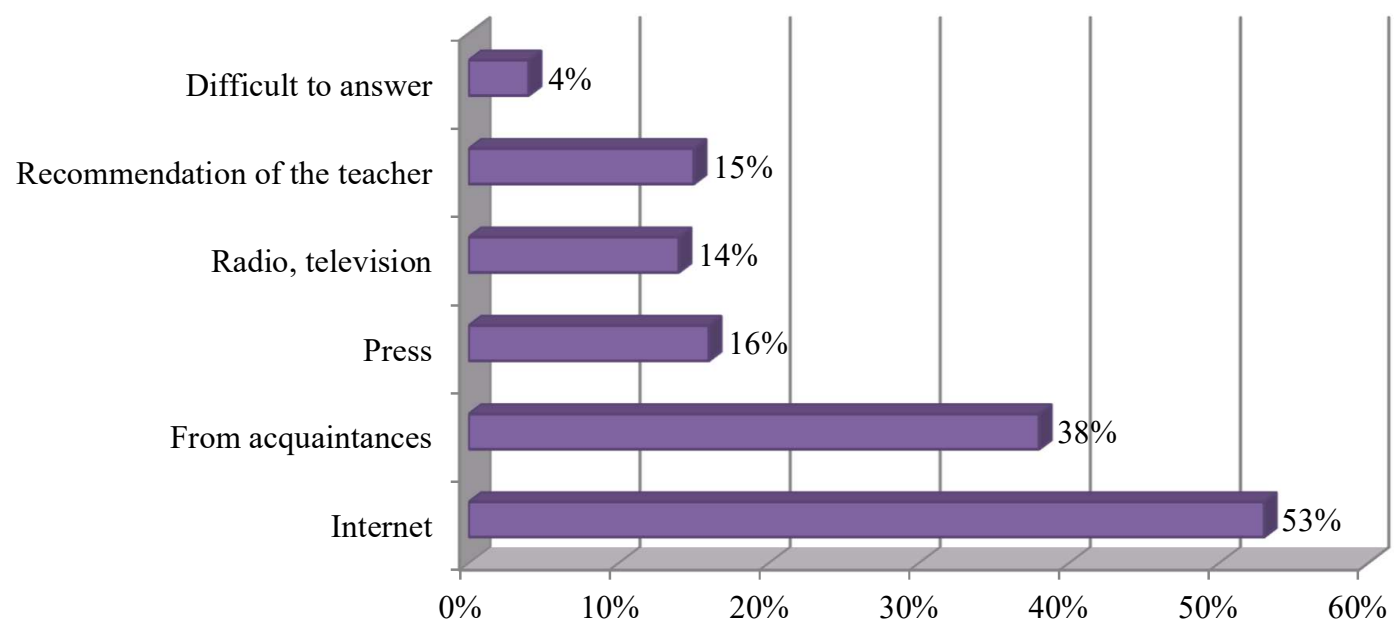

Fig. 5. Apprised About Holding Museum Actions (several possible answers, in \% of respondents)
Source: The results of the analysis of museum audience questioning of the Samara region.

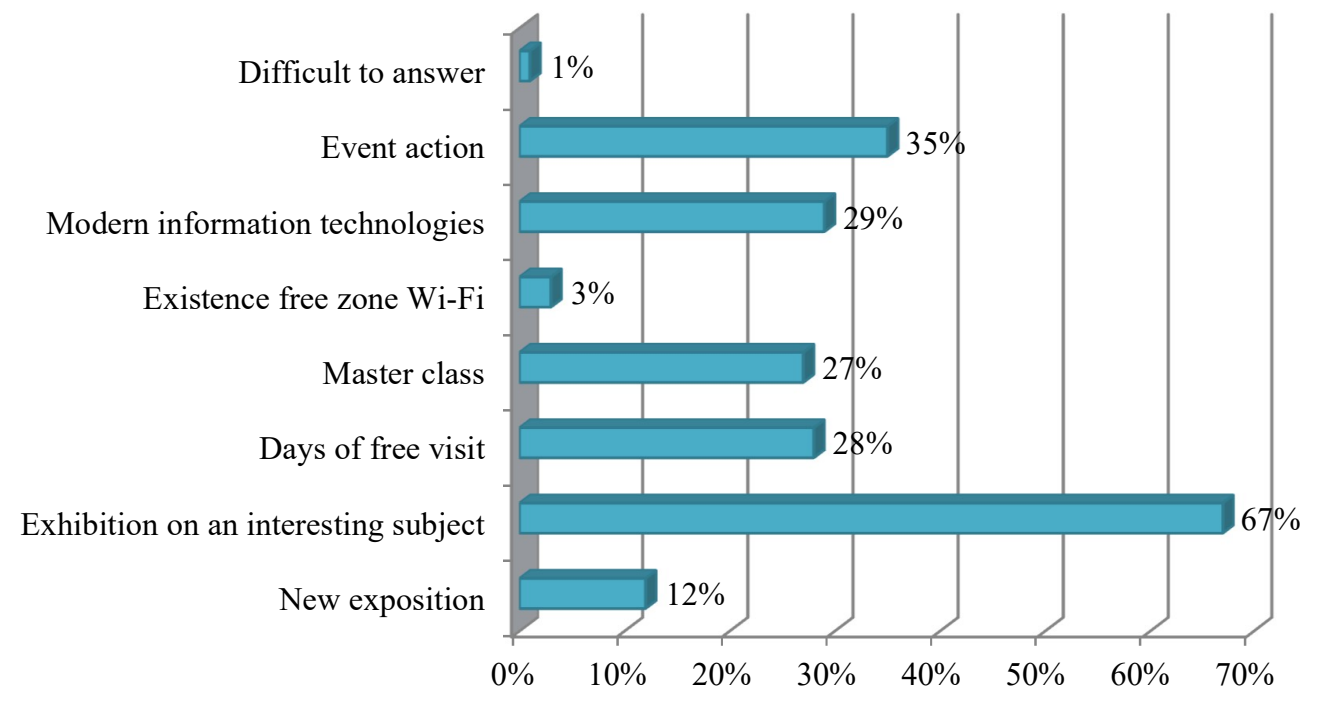

Fig. 6. The Factors Promoting Attraction of The Municipal Museums Visit (several possible answers, Source: The results of the analysis of museum in \% of respondents).

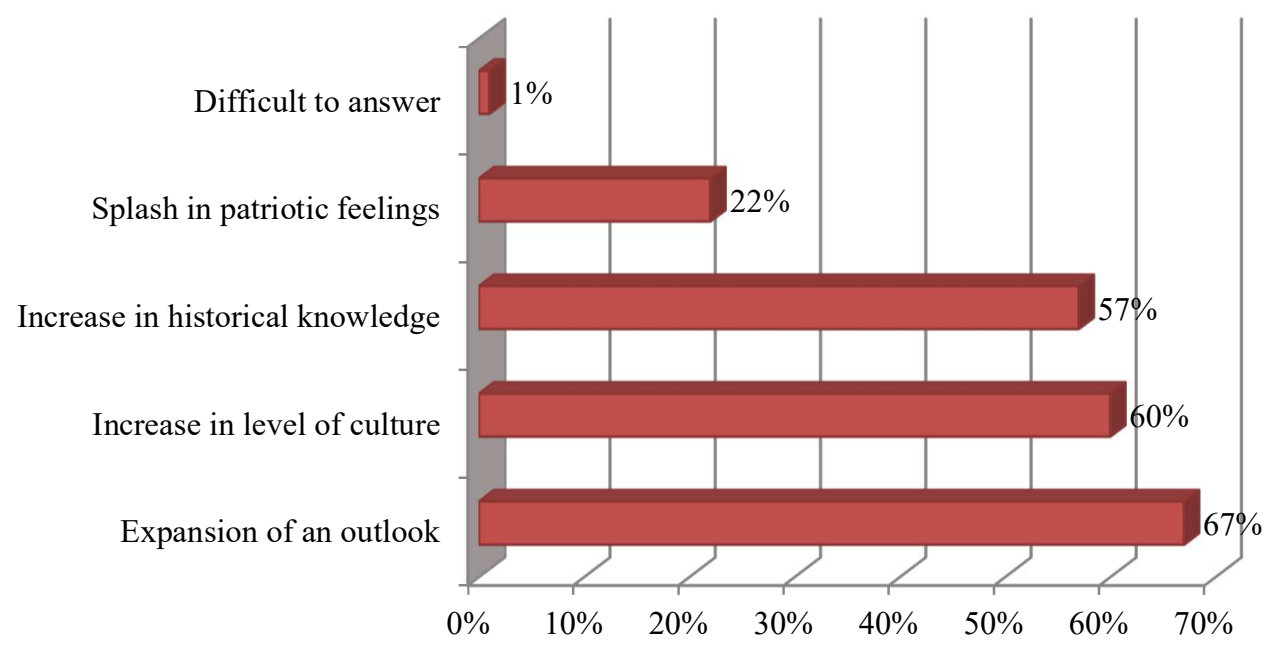


Fig. 7. Target Expectations of Visiting The Municipal Museum (several possible answers, in \% of respondents)

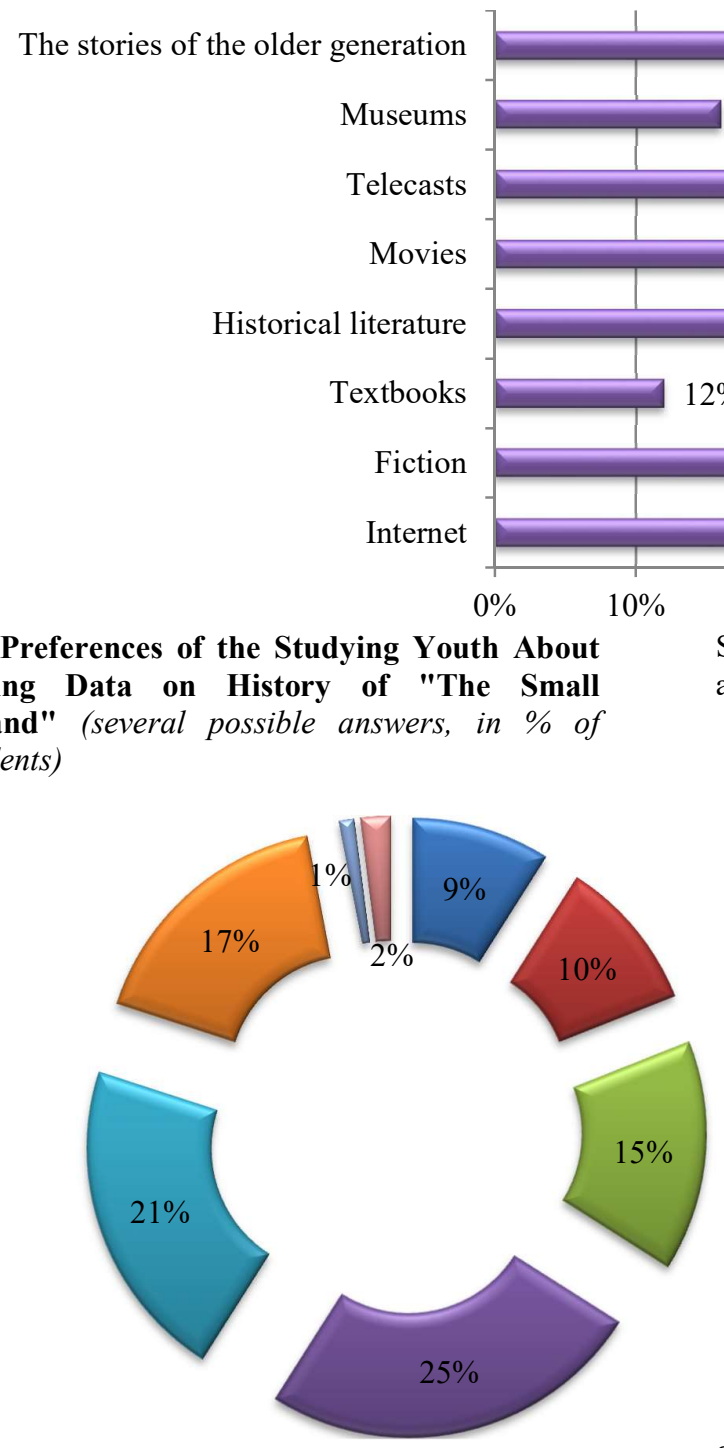

Fig. 8. Preferences of the Studying Youth About Obtaining Data on History of "The Small Homeland" (several possible answers, in \% of respondents)
Source: The results of the analysis of museum audience questioning of the Samara region.

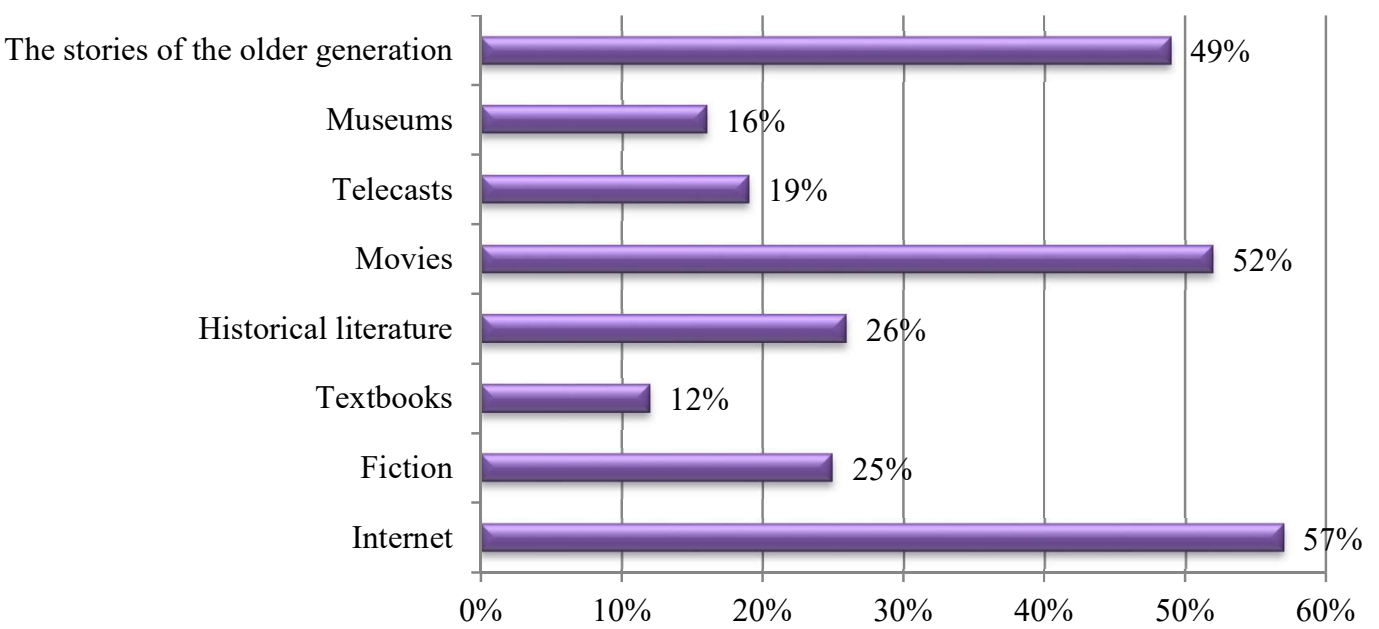

Source: The results of the analysis of museum audience questioning of the Samara region.

Fig. 9. (in \% of respondents) audience questioning of the Samara region.
Interest in various periods of national history.

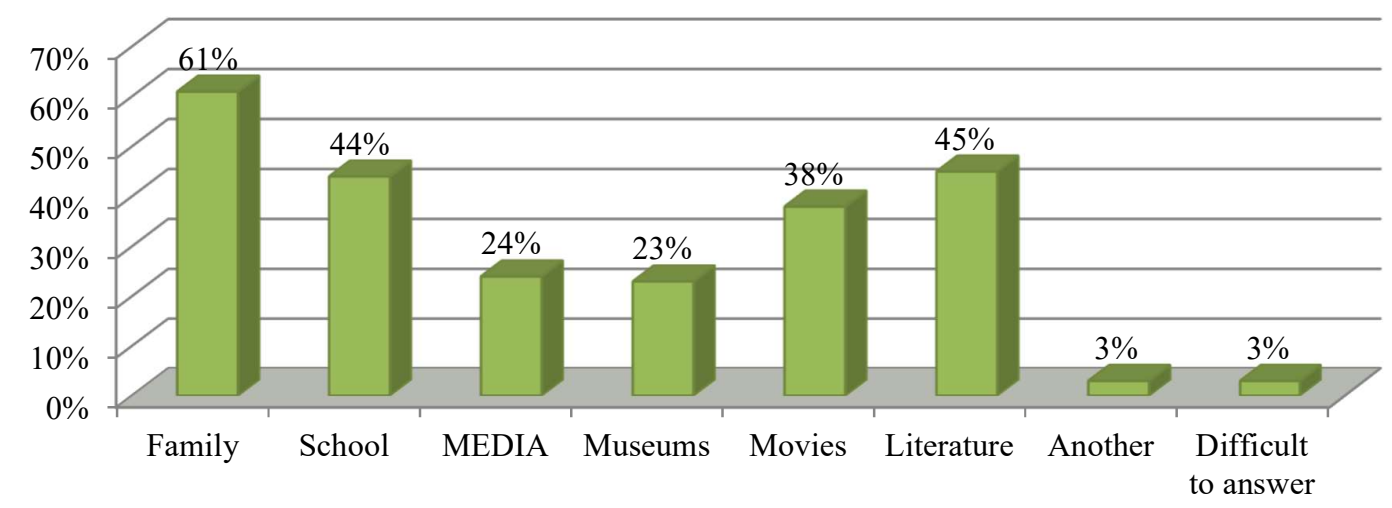

Fig. 10. The Factors Promoting Formation of Patriotic Consciousness (several possible answers, in $\%$ of respondents)
New exposition

घxhibition on an interesting subject

$\square$ Days of free visit

口aster class

$\square$ Existence free zone Wi-Fi

$\square$ Modern information technologies

$\square$ Event action

$\square$ Difficult to answer

Source: The results of the analysis of museum

.

Source: The results of the analysis of museum audience questioning of the Samara region. 


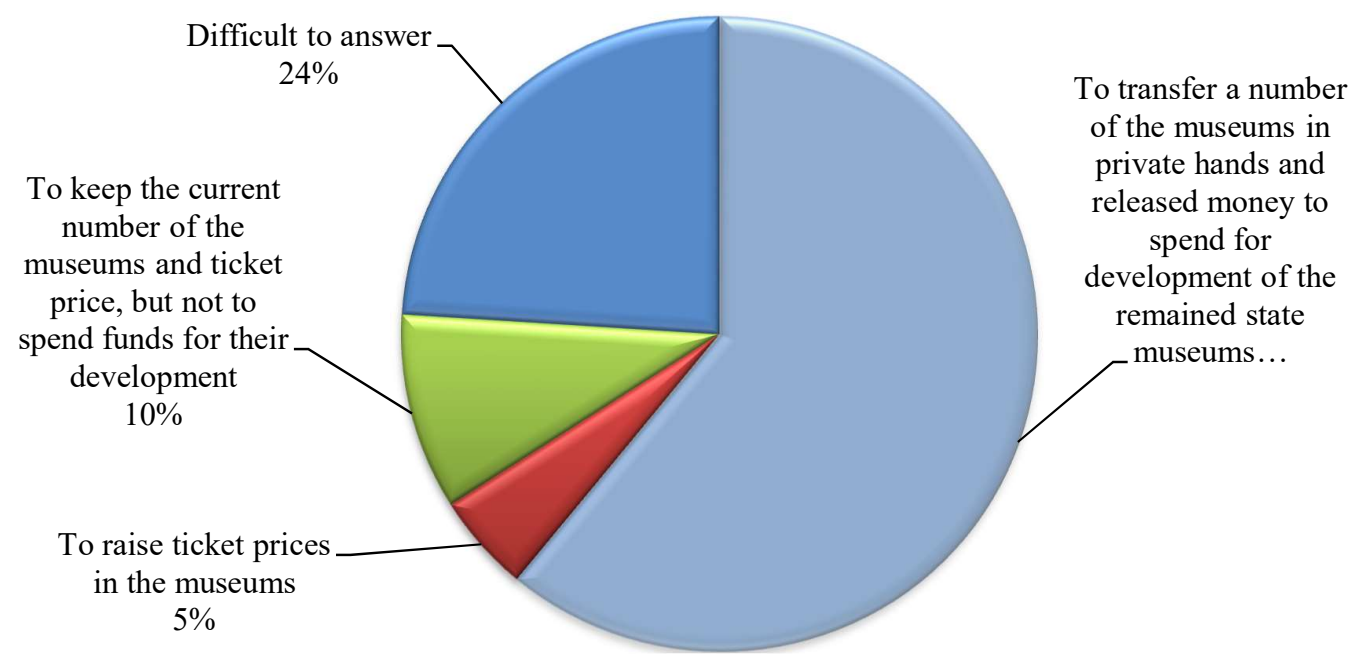

Fig. 11. Solution Museums Funding Problems (in \% The second part of the study can also be presented in of respondents) tabular form:

Source: The results of the analysis of museum audience questioning of the Samara region.

Tab. 2: The Municipal Museums of the Samara Region Participation in a Competition on the Best Tourist Route and the Used Technologies of Museum Business

\begin{tabular}{|c|c|c|c|c|}
\hline Museum's name & $\begin{array}{l}\text { Name and subject } \\
\text { of the project }\end{array}$ & $\begin{array}{l}\text { Inclusion in activity } \\
\text { (interactive } \\
\text { programs) }\end{array}$ & Staging elements & $\begin{array}{l}\text { Use of information } \\
\text { technology }\end{array}$ \\
\hline $\begin{array}{l}\text { Museum of local lore of } \\
\text { the Syzran district }\end{array}$ & $\begin{array}{l}\text { True stories and } \\
\text { legends of Syzran }\end{array}$ & No & Yes & No \\
\hline $\begin{array}{l}\text { School versatile local } \\
\text { history museum «Istoki» }\end{array}$ & $\begin{array}{l}\text { Native land pure } \\
\text { sources }\end{array}$ & No & No & No \\
\hline $\begin{array}{l}\text { «The museum of } \\
\text { Oktyabrsk - on - Volga» }\end{array}$ & $\begin{array}{l}\text { Regional Open } \\
\text { Festival «Bridge» }\end{array}$ & Yes & No & No \\
\hline $\begin{array}{l}\text { History museum named } \\
\text { after I.N. Ulyanova of } \\
\text { the Usolye region }\end{array}$ & $\begin{array}{l}\text { A fascinating } \\
\text { journey through } \\
\text { the history of } \\
\text { Usolye }\end{array}$ & Yes & Yes & No \\
\hline $\begin{array}{l}\text { Isaklinsky regional local } \\
\text { history museum }\end{array}$ & Edge of 100 keys & Yes & Yes & No \\
\hline $\begin{array}{l}\text { Museum of Local } \\
\text { History named after the } \\
\text { the Hero of Socialist } \\
\text { Labor N. Popov }\end{array}$ & $\begin{array}{l}\text { Travel to Irgiz's } \\
\text { secrets }\end{array}$ & Yes & No & No \\
\hline $\begin{array}{l}\text { Museum of Local } \\
\text { History } \\
\text { Department of the } \\
\text { municipal district } \\
\text { Bolsheglushitsky }\end{array}$ & Wilderness travel & Yes & Yes & No \\
\hline $\begin{array}{l}\text { Museum of Local } \\
\text { History } \\
\text { Luka» }\end{array}$ & $\begin{array}{l}\text { Trail fairy-tale } \\
\text { characters }\end{array}$ & No & Yes & No \\
\hline $\begin{array}{l}\text { Historical Modelling } \\
\text { Center «Ancient World» }\end{array}$ & Travel to the past & Yes & Yes & Yes \\
\hline
\end{tabular}

Source: The results of participation of the municipal museums Samara region in a competition for the best tourist route 
It should be noted that there are museums of local lore or the centers performing functions of the museum practically in all 27 municipal districts of the Samara region. But less than a half of such centers of culture have participated in a competition.

\section{Discussions}

The Museums Attendance by Young People. The rating of any museum, his public importance are defined by attendance level. The museums attendance consists of the individual viewers and visitors number as a part of excursion and lecture groups. According to the survey $62 \%$ of respondents go to a museum once a year or less, but $74 \%$ of respondents say that would go to museums more often, if there was such an opportunity. $3 \%$ of young people never have been in museums, in $9 \%$ of the respondents do not have a desire to visit museums (Figure 1).

The issue is urgent to increase traffic for existing museums as well as to assess the prospects for the opening of new museums, if any will appear. When asked about the desire to visit museums more often sample split: $74 \%$ of respondents would like to visit the museum often and $9 \%$ did not want to, and $13 \%$ were undecided (Figure 2).

More than two-thirds of respondents expressed a desire to visit museums more often, the percentage of those who find it difficult to answer this question is significantly higher than among those who visit the museum once a year or less. Let us try to explain this fact. Respondents who visit the museum more than once a year, is likely to have clear criteria on which the museum is estimated as the product of more or less interesting. This makes the option «difficult to answer» the most appropriate, since it is impossible to know for sure whether the exhibition in the museum, which seems interesting. However, this is only an assumption that needs to be checked (Tavrizyan \& Usanova, 2010) [7].

To the question «Have you ever visited the historical and regional museums in small towns and villages?» $75 \%$ of young people responded positively, $25 \%$ negatively. For half of the respondents seem to be the most interesting art museums and fine arts museums $(56 \%)$. Few in popularity behind the house-museum of famous people (43\%). Historical, regional museums occupy third place in the ranking of interest $(33 \%)$ (Figure 3).

The Younger Generation Awareness of Samara Region Provincial Museums. Distribution of answers to the question of knowledge of the Samara region provincial museums and what museums respondent ever attended, shows that the youth most often visited Repin I. E. House museum. in the village of Shiryaevo (38\%) (Table 1). It is possible to draw a conclusion that young people are informed on all large provincial museums of the Samara region, but the percent of their visit is low, having analyzed answers of respondents. Low provincial museums attendance can be explained by the fact that their cultural and information component attracts mostly locals. At the same time most museums of local lore look for new forms and try to reveal a natural and cultural originality of the territory. Museums of local lore execute important social function on preservation and maintenance of local history and culture.

The Reasons for a Rare Visit to The «Small» Museums. The most common reason is lack of time $(44 \%)$; second place $(40 \%)$ - the option «prefer to spend their leisure time differently»; third place - the answer is «away live» $(29 \%)$; version of «insufficient information» have chosen $26 \% ; 17 \%$ think that the campaign in a museum - it is boring (Figure 4).

In our view the main reasons for a rare visit to the «small» museums are interrelated. Young people spare time becomes smaller, so that its value is constantly increasing. Young tries to combine free time with the maximum benefit for themselves and use. Most young people prefer active leisure activities. Many provincial museum is associated with the old exhibits, unrelated to real life, with the worn material and technical base, lack of modern technology, interactive gaming and forms of interaction. This could be due to a fairly high percentage of respondents who believe that the visit to the museum - it is boring pastime. Ultimately, young people refuse to march to the museum and choose safe, from their point of view, the alternative of spending free time. For many respondents it is more important to spend leisure time relaxing and not «straining brains» in the museum (Hachatryan \& Chernega 2012) [8].

The problem of museum services availability for the rural and urban settlements residents is one of the most pressing and complex. Many residents are forced to give up visits to museums because of the remoteness of residence. Lack of time in this case is also linked to this cause - it takes a whole day to visit the museum, located many kilometers, much of which will be held in uncomfortable conditions of travel on not very reliable and rarely plying transport.

Effective Channels of Informing Museums Visitors. The most important factor of the museums attendance growth is the level of public awareness, and especially youth. Museum communication problems, interaction of the small district museum with the new visitor are the most urgent that illustrates the conducted survey («There isn't enough information» $26 \%)$. 
The main source of information for young people is the Internet, but as evidenced by the level of information analysis of local history museums in the district of Samara region, only 3 museums have their own Internet sites, two of which - not active

(Tavrizyan \& Usanova 2010) [7]. For the objective reasons (financial, organizational) the small district museums have no opportunity to be integrated into electronic museum community, and still remain in information «blockade». However, the range of information revealed preferences of the museum audience, highlights the need for more active post information on the Internet as a way to create their own Web sites, as well as on a single portal combining museums (such as the portals «Museums of Russia», «Kultura.rf», «Museums of the Sverdlovsk region», «Shadow of Peter», portal science museums of the Siberian Branch of Russian Sciences Academy, and others).

As can be seen from the data, to obtain information about museums, exhibitions, expositions, respondents are quite a wide range of information resources (Figure 5). In explaining the most popular channels of information dissemination about museum events and exhibitions poll results have recorded an important part of the information resource as the Internet. More than half of the museums visitors said that often get their information from this source.

Further, by a considerable margin followed by such sources as the stories of friends, the media, the recommendation of the teacher. Its environment as an information channel named $38 \%$ of respondents. It is also important that the information resource is not accidental. For many of the respondents important is not so much to obtain specific information about the museum's product as a subjective evaluation of their social acquaintances. Such assessments often have a decisive influence on the event or a visit to the museum exhibitions, sometimes even creating a specific mode of conduct.

The share of the visitors who have come to the museum according to the recommendation of teachers is rather small $(15 \%)$ though the share of pupils of schools, technical schools, higher education institutions among visitors is considerable. It is necessary to look for new forms of interaction of the museum and educational institutions: for example, placement of announcements of the museum in educational institutions. Due to the transition to "online magazines" and substantial increase of a role of computer technologies in educational process it is necessary to use as much as possible electronic resources in the course of interaction with school, technical school, higher education institution. Practically with the same frequency such information resources as the press, radio and television are used by museum audience.

Target Orientation of the Museum Audience. During the research task was to determine the factors that contribute to attracting young people to visit the municipal museums (Figure 6). More than a half $(67 \%)$ of the interviewed potential visitors have indicated exhibit an interesting topic for them as such factors.

We can conclude that the interest in traditional crafts is large enough, comparing the responses of young respondents to the question, what could attract them to visit the museum in the province. This is evidenced by the fact that almost a third of respondents from among attract real visitors to visit the provincial museums workshop.

Besides, as show results of a research, the recreational function of the museums is very important both for real, and for regular customers. They are waiting for the museum vivid impressions, emotional recovery, a festive atmosphere, transfer to another, in comparison with the everyday reality. This is evidenced by the preference given to potential visitors in this eventcultural and educational activities, as a festival, fair, folk festivals, meeting with interesting people.

Modern information technology in the museum attracted $29 \%$ of respondents. Multimedia is not only electronic means, it is a way of interaction of the museum and the visitor. With a total load of information society, bright presentation of information about the museum exhibit or theme in the form of copyright installations using multimedia technologies allows you to leave more impressions in the memory of the subject and the overall feeling of a more interested by visiting the museum.

By results of poll it has become clear that $28 \%$ of young people would visit the museum in days of free visit. However very few school students and students are informed on the right of free visit of the state and municipal museums once a month. Law «On Amendments to Article 12 of the RF Law «Fundamentals of Russian Federation legislation on culture» was adopted by the State Duma in the second and third readings of 15 April 2014, and two weeks later approved by the Federation Council (Official Internet portal of legal information 2015) [9].

The study targeted the expectations of potential and actual users of municipal museums have been identified (Figure 7). The survey showed that the effect of visiting the museum on the Reformation of such personal qualities as expanding horizons, enhance the level of culture, enhance historical knowledge, the burst of patriotic feelings as follows. Most young people (67\%) expect to expand their horizons. In this sense, exploring new places for young people - this is one part of their educational strategy. 
It is also highly rated by respondents the effect of visiting the museum to raise the cultural level and historical knowledge. Almost all the respondents noted a link between local history and patriotism. However only $22 \%$ of respondents expect from visit from the museum a splash in patriotic feelings and pride of the small Homeland. Many young people see the museum as a platform for the secure storage of valuables, despite the fact that manifested a clear trend towards the use of historical museum, not only in the educational and developmental purposes, but also as a reference base of spiritual, moral and patriotic education of youth.

Historical and Patriotic Consciousness of Youth. An important objective of the study is to reveal the extent of formation of moral and patriotic and historical consciousness of youth. To this end it has been undertaken to establish the preferences of young people about how to obtain information about the history of the «small motherland».

Analyzing the survey materials, we can conclude that the knowledge of young people in the history of the «small motherland» are focused on the information obtained from the Internet (57\%), movies (52\%) and from the stories of the older generation (49\%) (Figure 8).

Educational literature as a source of data on history of «the small Homeland» was called by only $12 \%$ of respondents. It is quite unexpected, though explainable result. The knowledge gained from textbooks, but often exactly until in them there is a pragmatical need connected with safe passing of examination remains. Sometimes it reveals contradictions obtained using different historical sources. The most common of them - the contradiction between the textbook and the stories of the older generation. In this dispute, as a rule, winning the memories of a loved one.

Municipal museums are not included in the number of basic preferences for obtaining information about the history of the «small homeland» (16\%). Importantly, significant interest to historical events are mainly expressed in the passive form. It means that, despite a big level of trust which is put in the museums the youth uses generally such forms of obtaining historical knowledge as the Internet, movies, publications, literature. The museums which represent the active form of mastering of history remain not peripheries of educational process yet.

Of great importance in determining the priority forms of museum activities in order to maximize the integration the needs of different visitors groups is keeping interest in certain periods of national history (Figure 9).
Data of poll show that young people are interested in practically all listed periods of history of Russia. Particular interest among respondents is attracted by history of the Russian Empire 18 beginnings of 20 centuries, and also the Soviet period.

Suffice it important for the study was to identify factors that contribute to the formation of patriotic consciousness of the population (Figure 10). The greatest number of respondents agreed that the family is a basis for patriotism forming (61\%) as in a family the outlook foundation is laid, the civil responsibility is created. Value of school is also big (44\%). Educational institutions are the main institution that provides educational process and the integration of the various forms of patriotic consciousness education.

Today, the younger generation about patriotism speak more often, and love for the motherland becomes a powerful emotional motivation in the public consciousness. There has been increased interest in the history, national heroes in the domestic arts, including film and in literature (Yakunin et al., 2016) [10]. The survey showed that among the factors that influence the patriotic consciousness, movies play an important role $(38 \%)$ and books $(45 \%)$. An example of the best people life of our motherland is developing in the younger generation of the people perfect images whom they would like to be like. By means of art formed the system of moral ideals and principles that determine the subsequent behavior.

A significant role in formation of patriotic consciousness is played by mass media (24\%). Ideology of modern society, especially young, media build: television, newspapers, Internet. Not always this «construction» goes in the right direction, but there are no doubts that modern media render on him defined and even very strong - influence. And if the senior generation had already had certain installations in the patriotism relation so materials of the press can only correspond or contradict him, then the generation of young people still is in a self-determination stage, and, therefore, impact of printing and electronic editions on him has the most pronounced character.

Museums occupy is not the main place among the factors contributing to the formation of the youth patriotic consciousness $(23 \%)$. Although at present the museum is one of the leading forms of patriotic, civil and general cultural education of the younger generation, integrating the purpose of forming the individual citizen of Russia, many young people see the museum as a platform only for the storage of historical values (Polyanskova \& Sherstobitova 2014) [11].

We can not dwell on the problems of traditional municipal museums. A key problem is the limited financial resources allocated from the local budgets museums (Polyanskova \& Nuykina 2015) [12]. The 
economic crisis is worsening financial support of municipal cultural institutions. Respondents were asked about how to deal with the financing of museums due to the difficult economic situation in the country (Figure 11).

Priorities of The «Small» Museums Development in The Eyes of Youth. By results of poll it has become clear that most of young people find it possible to give a priority to these or those museums, having transferred a number of the museums in private hands and released money to spend for development of the remained state museums $(61 \%)$. The assumption that the younger generation indifferent to the problems of museums, has been refuted. Only one tenth of the respondents said that everything should be left as is, $24 \%$ of respondents were undecided.

The Analysis of Results of The Municipal Museums Participation in a Competition on the Best Tourist Route in general has confirmed conclusions of sociological poll. The insignificant share of the museums among participants of a competition says that not all heads of such institutions see in development of internal tourism means of increase in the museums attendance, and the activity by the way of increase in tourist appeal of the territory.

At the same time, museums contestants show a high level of integration of its own audience preferences. The majority of the projects which have arrived on a competition are connected with tourist events with the participation of the museums or interesting expositions devoted to history of primitive society, history of edge of the period of the Russian Empire or the Soviet Union.

Most projects contestants have elements of staging (the use of costumes, household items, restoration of ceremonies), as well as interactive programs, including the tourist in activities for reconstruction of the ancient crafts, folk dancing, cooking traditional national dishes.

It should be noted the weakness of information support of the museums activities as the domestic tourism resources. Only expositions and excursions of the center of historical modeling «The ancient world» are widely presented to the Internet, the website is followed by the map of the drive, provides a possibility of own tour modeling (though only in certain days) and contains a 3D panorama of the museum territory.

\section{Conclusion}

Based on the results of the study, it is possible to formulate a number of practical recommendations that contribute to attracting students to the museums and the development of tourist activities of cultural centers:

- it's necessary an active introduction the information and communication technologies in the museums work, the museum promotion through the Internet, the creation and updating of the active site;

- intensive development of educational and entertainment programs, the organization of new interesting exhibitions with use of modern interactive methods, the inclusion of these programs and exhibitions in the tourist routes organized by the museums or tourist companies;

- it is necessary to work out a program to optimize the museums placement in rural areas in order to implement the affordability of museum services for the village residents, far from the district center, as well as more active use of the practice of traveling exhibitions, master-classes in the towns, where there are no museums.

Activities of the provincial museums can become effective if the museums, keeping specifics, national traditions, will keep pace with the times, developing creativity, creativity and identity of the activities, accumulating a maximum of resources from the external environment, including changing of financial investments structure in museum case at the expense of the raised funds.

\section{References}

1. Chibir, E. \& Shirko, T. (2015). Event tourism in Russian region: opportunity for small-scale business growth. Procedia Economics and Finance, 26, pp. 183 - 187. Retrieved from: http://ac.els-cdn.com/S2212567115009168/1s2.0-S2212567115009168main.pdf?_tid=ff556a16-a35811e6b41a000aacb35e\&acdnat $=1478351511$ 9de $15 \mathrm{dbd} 904 \mathrm{e} 53582 \mathrm{f} 19 \mathrm{c} 22069 \mathrm{bf} 27 \mathrm{ca}$

2. Dzhandzhugazova, E.A., Ilinaa, E.L., Latkin, A.N. \& Koshelevava, A.I. (2016). Developments of Creative Potential of Cinema Tourism. International Journal of Environmental \& Science Education, 11 (11): 4015-4024. Retrieved from: http://www.ijese.net/makale/620

3. Jakosuo, K. (2011): Russia and the Russian tourist in Finnish tourism strategies - the case of the Karelian region, Procedia Social and Behavioral Sciences, 24: 1003- 1013. Retrieved from: http://www.science direct.com/science/article/pii/S18770428110154 36

4. Joseph, B., Pine, I.I. \& Gilmore, J.H. (1999): The Experience Economy: Work Is Theater \& Every Business a Stage. Boston, MA: Harvard Business Review Press: 272 p. 
5. Surugiu, M.-R., \& Surugiu, C. (2015). Heritage tourism entrepreneurship and social media: opportunities and challenges. Procedia Social and Behavioral Sciences, 188, pp. $74-81$. Retrieved from: http://www.sciencedirect.com/science/article/pii/ S1877042815021333.

6. Throsby, D. (2001). Economics and Culture. Cambridge: Cambridge University Press, 208 p.

7. Official Internet portal of legal information. (2015). Retrieved from: http://pravo.gov.ru/proxy/ips/?docbody $=\&$ nd $=10$ 2383006\&intelsearch $=\% \mathrm{D} 4 \% \mathrm{E} 5 \% \mathrm{E} 4 \% \mathrm{E} 5 \% \mathrm{~F} 0 \%$ E0\%EB $\%$ FC\%ED $\%$ FB $\%$ E9+\%E7\%E0\%ЕA\%E $\mathrm{E} \% \mathrm{ED}+\% \mathrm{EE} \% \mathrm{~F} 2+28+\% \mathrm{ED} \% \mathrm{EE} \% \mathrm{FF} \% \mathrm{E} 1 \% \mathrm{~F} 0$

$\% \mathrm{FF}+2015+\% \mathrm{E} 3 \% \mathrm{EE} \% \mathrm{E} 4 \% \mathrm{E} 0+\mathrm{N}+357-$

$\% \mathrm{D} 4 \% \mathrm{C} 7$

8. Polyanskova, N.V. \& Nuykina, E.Yu. (2015). Samara State University of Economics at the II International Museum Forum: and the results of the project initiatives. Regional development: electronic scientific journal, 6 (10). Retrieved from: https://regrazvitie.ru/samarskijgosudarstvennyj-ekonomicheskij-universitet-naii-mezhdunarodnom-muzejnom-forume-itogiraboty-i-proektnye-initsiativy/

9. Polyanskova, N.V. \& Sherstobitova, G.I. (2014). The interaction factors analysis of the museum environment and cultural and informative tourism in moral and patriotic education of youth. Vestnik of Volzhsky University after V.N. Tatischev, 2 (31), pp. 166176.

10. Yakunin, V.N., Ovsyannikov V.P., Lepeshkina L.Y., Nikitina N.V., Skornichenko N.N. \& Alexeyeva N.D. (2016). The Role of Traditional Culture in Formation of Historical Image of Agglomeration. International Business Management, 10 (7), pp. 1375-1381. Retrieved from: http://medwelljournals.com/abstract/?doi=i bm.2016.1375.1381.

11. Tavrizyan, Yu.B. \& Usanova, O.V. (2010). Qualitative analysis of consumer services of the museum as an example of the Perm State Art Gallery. Materials of scientific-practical conference «From the flash mob to the directory: the museum in the social space of modern Russia», pp. 123-128.

12. Hachatryan, L.A. \& Chernega, A.A. (2012). A social advantage of museum for studying youth: essence and problems. Perm University Herald. Series «Philosophy. Psychology. Sociology», 2 (10), pp. 167-172 